\title{
La profundidad de Dios \\ El nihilismo místico implícito en el pensamiento de Eckhart
}

\author{
HÉCTOR SEVILLA GODÍNEZ* \\ Universidad de Guadalajara (México) \\ hectorsevilla@hotmail.com
}

\begin{abstract}
Resumen
El principal objetivo de este escrito reside en mostrar algunos de los elementos esenciales del proyecto eckhartiano que están fusionados con una mística nihilista que observa (sin observar) en la nada una manifestación de la deidad, es decir, una Nadeidad. De hecho, en este artículo se introduce el término referido, comprendiéndolo como una propuesta sobre las maneras de concebir a lo sagrado a partir de la contemplación de la Nada. La atención se centra en algunos sermones elaborados por Eckhart, en dos de sus tratados y en la Bula con la que fueron prohibidos sus escritos.
\end{abstract}

Palabras Clave: Nada, Deidad, Eckhart, Mistica, Nihilismo.

\section{The depth of God \\ The implicit mystical nibilism in the thought of Eckhart}

\begin{abstract}
The main objective of this piece resides in demonstrating some of the essential elements of the Eckhartian Project that are fused to a nibilistic mysticism that observes (without observing) a manifestation of the deity in nothingness; this is to say, a Nothingeity. In fact, said term is introduced in this article, understanding it as a proposal about the manners in which to conceive that which is sacred, based on the contemplation of Nothingness. The attention is centred on some of the sermons elaborated by Eckhart, on two of his treaties and on the Bull, with which his writing was prohibited.
\end{abstract}

Key Words: Nothingness, Deity, Eckhart, Mysticism, Nibilism.

\footnotetext{
* Doctor en Filosofía por la Universidad Iberoamericana de la Ciudad de México. Miembro del Sistema Nacional de Investigadores, de la Asociación Filosófica de México y de la Asociación Transpersonal Iberoamericana. Es profesor e investigador del Departamento de Ciencias Sociales y Humanidades del Centro Universitario de los Valles en la Universidad de Guadalajara. Ha publicado diversos libros entre los que sobresalen Contemplar la Nada (2012), Resonancias de la Nada (2013) y el Vacio de Dios (2014). También coordinó el libro colectivo Analogías Alternantes de la nada (2015).
} 


\section{INTRODUCCIÓN}

Eckhart de Hochheim (1260-1328), dominico alemán y maestro de Teología en París, mejor conocido como Maestro (Meister) Eckhart. Su brillantez y lucidez son debidas, en gran parte, a su capacidad para traspasar los cánones establecidos en lo que respecta a la comprensión, acercamiento y contemplación de la divinidad. Su propuesta filosófico-teológica, que apunta hacia una cima no visualizada por otros dominicos y predicadores de su tiempo, aún hoy continúa siendo parcialmente desconocida en Latinoamérica, probablemente por la poca difusión de sus obras en español o, en su debido caso, por la prohibición eclesiástica a sus escritos durante más de seiscientos años. Su congruencia en el pensar y el actuar le valieron la admiración y la persecución, ambas en alta proporción. Su trabajo fue ampliamente conciliador, buscaba conjuntar la razón y la fe; si bien señaló con agudeza los errores de los que siguen a Dios con actos pletóricos de poca sutileza, también indicaba la alternativa óptima para lo que él consideró un plan de vida consagrado. Con toda claridad, "el proyecto eckhartiano estaba dirigido a mostrar la unidad del conocimiento más que a señalar las diferencias entre la luz natural del intelecto y la sobrenatural de la fe" (Vega, 2011: 28). En este camino, Eckhart sintetizó sólidamente algunas de las perspectivas propias de la mística; la conocida expresión gelâzenheit (abandono) tiene un amplio andamiaje en lo propuesto por el dominico.

La obra de Eckhart causó gran interés en la filosofía del último siglo, al grado que Heidegger realiza varias menciones del Maestro en diversos pasajes de su obra, incluyendo las referencias en su escrito de habilitación Las categorías y la doctrina de la significación en Duns Escoto, o en textos posteriores como ¿Qué significa pensar?, El sendero de campo y La pregunta por la cosa. Con ello, puede afirmarse que "Heidegger no sólo conocía el pensamiento de Eckhart, sino que incluso lo ha tenido presente de un modo u otro, desde los comienzos hasta la última etapa de su derrotero intelectual" (Filippi, 2003: 34).

En Oriente, el pensamiento de Eckhart está presente en Nishitani quien lo asoció al Así hablaba Zaratustra de Nietzsche. El japonés también relacionó al Maestro con el pensamiento de Heidegger, así como con el nihilismo europeo y la mística alemana en general, específicamente a partir de las coincidencias en sus abordajes sobre la nada. Para Nishitani (2003), la superación de la miope concepción de la "nada relativa" (relative notbingness), desde la cual se forjó el nihilismo europeo, sólo puede lograrse partiendo de una mirada a la "nada absoluta" (absolute notbingness), la cual está relacionada totalmente con todo lo que es. En ese sentido, la mística nihilista del Maestro puede encontrar similitudes con el budismo Zen en su 
intención de lograr la liberación absoluta, ya sea por mediación de la mors mystica eckhartiana, en la que el individuo ruega a Dios que le vacíe de Dios, o la Gran muerte, entendida en el Zen como una conversión radical del espíritu; esto último, de acuerdo a Tanabe (2014) puede constituir la pauta para el logro de una metafilosofía.

En su elogiable obra La religión y la nada, Nishitani afirmó que Eckhart consideraba la esencia del Dios personal como una nada absoluta; concretamente, como un "campo de muerte-en-la vida absoluta" (Nishitani, 2003: 143). En ese sentido, afirma el filósofo oriental, "el mismo Eckhart declaraba que el fondo de Dios reside en el interior del sí mismo, más próximo al sí mismo que lo que éste lo está de sí mismo" (Nishitani, 2003: 143) y lo equipara con la idea budista del sûnyatâ el cual es "el lugar en el que nos manifestamos en nuestra propia mismidad" (Nishitani, 2003: 144). También pueden encontrarse lugares comunes entre la tradición Mahâyâna, cuyo mayor representante es Nâgâryuna y la experiencia de la nada o vacío eckhartiano.

Eckhart solía rehusarse a promover una teología instrumental, centrada en dogmas y convenciones. Tal como se observará en el presente texto, Eckhart negó cualquier nominación o modo en Dios; consideró que el vacío supremo del alma es el único lugar susceptible de recibir la acción de Dios. Por lo tanto, el principal objetivo de este escrito reside en mostrar algunos de los elementos esenciales del proyecto eckhartiano que están fusionados con una mística nihilista que observa (sin observar) la nada de la deidad, es decir, una Nadeidad.

La atención será centrada a los catorce sermones compilados en la obra El fruto de la nada, en la cual se recogen además dos tratados elaborados por Eckhart en distintos momentos de su vida, así como la Bula con la que fueron prohibidos sus escritos. El método de análisis será el hermenéutico centrado en los textos del autor referido. En cada aspecto analizado se aludirán reflexiones en torno al tópico central del artículo: vincular la mística eckhartiana con el punto de vista de la vacuidad.

\section{NiHILISMO MORAL COMO PAUTA DE LA MÍSTICA}

Eckhart buscó en el alma vacía (ledic) un modelo de misticismo en el que la forma principal fuera un estado informe. En ese sentido, el nihilismo moral e intelectual de las expresiones eckhartianas promueve un significado alterno al término nihilista en la metafísica moderna y contemporánea. No se trata, en este caso, de una negación de las cosas, sistemas, personas o credos, con la intención de permanecer en el desánimo sino, más bien, de prepararse, en tal punto de pureza, para la recepción de algo superior. 
En su sermón titulado El templo vacio, pronunciado en 1326, Eckhart (2011a: 54) menciona que "Dios quiere tener el templo vacío, para que allí dentro no haya nada que no sea él". El espacio vacío (leerer raum) al que refiere el Maestro debe entenderse desde una lógica paradójica del lenguaje simbólico y místico en el que estar vacío de sí mismo supone lograr estar lleno de Dios (Seiner selbst leer sein heisst Gottes voll sein). El vacío, como analogía de la nada implicada, debe ser tan radical que implique a esta última, de modo que se propone mantenerse tan vacío de todo "como vacía es la nada, que no está ni aquí ni alli’’" (Eckhart, 2011a: 55); además, el individuo debe llegar al punto de no pretender absolutamente nada. Si se sigue el camino alterno, es decir, el de aquellos a los que Eckhart critica por su visión mercantil de Dios, no se logra ser poseído por la divinidad. En uno de sus sermones, el Maestro alude a la noción de mercaderes, la cual él mismo adjudica a aquellos que pretenden encontrar en la religión una especie de oportunidad de transacción, en la que lo que se ofrece a Dios deberá traer una consecuencia benéfica a manera de intercambio o trueque. Eckhart apunta lo siguiente:

Mirad, mercaderes son todos aquellos que se preservan de los pecados graves y a quienes les gustaría ser gente de bien y hacer buenas obras para agradar a Dios, como ayunar, velar, rezar y cosas por el estilo; todo tipo de obras buenas, y las cumplen con el fin de que Nuestro Señor les dé algo a cambio o que Dios haga algo por ellos que sea de su agrado: todos ellos son mercaderes (Eckhart, 2011a:54).

La idea de "templo" en Eckhart es similar a la paulina, es decir, se refiere al interior. Cuando ése templo se vacía de todos los impedimentos, los atributos personales y la ignorancia, logra su armonía. En esas condiciones, es posible que brille majestuosamente con la claridad del Dios increado. Es por ello que la pregunta central del sermón titulado La virginidad del alma es la siguiente: "¿Cómo puede el hombre que ha nacido y alcanzado una vida intelectual, quedar vacío de toda imagen como cuando todavía no era?" (Eckhart, 2011b: 61). No obstante a que el vaciado del alma puede ser relacionado a la desapropiación, la negación de los atributos o cualidades personales (eigenschaften), o el rechazo a lo que se es, sólo a través de tal consigna se logra lo verdaderamente vitalizador. Es un nihilismo fecundo que se orienta a la construcción de una nueva identidad sin yo. El hombre que busca equivocadamente "lo suyo" en la diferencia con los otros, no ha logrado ser persuadido de que el desprendimiento de todo atributo y la aniquilación de toda diferencia con otros es el antecedente necesario para encontrarse como hombre nuevo, lo cual propone Eckhart. El estado virginal, asociado a la vacuidad del alma pura y libre, es remitido 
por Eckhart al estado anterior a la creación y previo al haber nacido. El vaciado ha de lograrse también respecto a las imágenes de Dios, el desapego a ellas. Esta mística promueve, naturalmente, un paso alterno a la religión tradicional, centrada en formas, apariencias y lineamientos predefinidos por mediación racional. Cuando Eckhart refiere a una potencia más allá del intelecto y de la voluntad, supera las mediaciones mercantilistas de los nombrados mensajeros de Dios.

\section{EL FONDO DE DIOS}

Al lograr un pleno vaciado, el hombre está apto para penetrar el fondo de Dios, pues se ha constituido en él. El fondo íntimo (in dem innersten grunde) en el que toda la bondad pertenecía al hombre increado fue también donde tuvo lugar el nacimiento de Dios; así, la pretensión es lograr que la naturaleza humana retorne al sitio donde fue originalmente incluida, es decir, en el sostén de la naturaleza divina. Ahí, en el sin modo, es donde está el modo de Dios. Precisamente, "quien busca a Dios según un modo toma el modo y olvida a Dios, que se oculta en el modo. Pero, quien busca a Dios sin modo, lo comprende tal como es en sí mismo" (Eckhart, 2011c: 72). El fondo de Dios es el lugar insondable que escapa a las condiciones espacio-temporales, su fondo es abi en donde todo se hace nada. Por ello, "el fondo de Dios es mi fondo, y mi fondo es el fondo de Dios" (Eckhart, 2011c: 72); coincidentemente, "Dios no pide otra cosa de ti, sino que salgas de tu modo de ser creatural y que dejes a Dios ser Dios en ti" (Eckhart, 2011c: 73). El "fondo sin fondo" (grunt âne grunt), homólogo al desierto (einöde) eckhartiano, logrado por el "saber sin saber" (wîse âne wîse), evidencia el absurdo de cualquier denominación de Dios. Permanecer en la desnudez, que permite la contemplación del fondo sin fondo, es una condición lograble a partir del autoextrañamiento de uno mismo, muy distinto al autoconocimiento tan orgullosamente proclamado en distintas tendencias y disciplinas. El saberse distinto a lo que uno cree de sí inicia el camino del extrañamiento hacia lo que hemos representado al atribuir características confiables, estáticas y aparentemente inmóviles a nuestra supuesta esencia personal.

Eckhart (2011c: 73) advierte, refiriéndose a la noble voluntad divina, que "todas las cosas han sido creadas de la nada; por eso su verdadero origen es la nada y en la medida en que aquella noble voluntad se inclina hacia las criaturas, cae con éstas en su propia nada". Antes del regreso a ese fondo sin fondo de la Nadeidad, es oportuno acercarse parcialmente en vida; para ello, la pureza producida por el ejercicio de vaciamiento es una forma de ascética negativa que libera al individuo de las impurezas de la naturaleza creada. El fondo (grunt) es el sitio sin sitio (locus non locus) en el 
que se desvanecen las nominaciones, estructuraciones e imágenes de Dios partiendo de un signo, o en razón de una cosa u objeto tangible o intangible; así, la búsqueda de Dios no supone un lineamiento específico a no ser que éste sea la nada de Dios y, por tanto, la tiniebla incomprensible de la deidad o, en otras palabras, la negación de la negación, la nonada (versagen des versagennes, nibtes nibt). En todo esto se observa que Eckhart insiste en que el hombre ha de salir de sí mismo para encontrar su vida; paradójicamente tal salida constituye también su entrada.

Eckhart recuerda constantemente a sus oyentes que "si alguien conoce algo en Dios y le atribuye un nombre, esto no es Dios. Dios está sobre los nombres y la naturaleza" (Eckhart 2011j: 116). Si Dios está por encima de todo lo visible, está más allá del tiempo. Su ser más allá del tiempo radica en la nada de su ser, su no-ser que es, su Nadeidad.

\section{UNIDAD CON DIOS EN LA NADA}

Para Eckhart, liberarse de los atributos personales permite una entrega verdadera a quien es libre por sí mismo: Dios. Por tanto, la plena aceptación de su voluntad logra que el hombre evada los juicios sobre el bien y el mal, el más y el menos, dejándole así indiferente ante los criterios del mundo. En este punto se vive una fusión tal con Dios que no existe división. En palabras del dominico: "Si recibiera algo de Dios estaría por debajo de Dios como un sirviente y él, al darme, sería un Señor. Pero esto no debe sucedernos así en la vida eterna" (Eckhart, 2011d: 81). Es tal la adhesión lograda, en el punto en que cada uno es un Uno, que Eckhart (2011d: 78) afirma: "el ser de Dios es mi vida. Si por tanto mi vida es el ser de Dios, entonces el ser de Dios tiene que ser mi ser y el ser esencial de Dios mi ser esencial, ni más ni menos". La relación no está delimitada únicamente por el contacto, sino que es desembocante en una penetración: "por el conocimiento concibo a Dios en mi interior; por el amor, por el contrario, penetro en Dios" (Eckhart, 2011d: 81). No existe necesidad de ver a Dios como un dador Omnipotente del que se reciben servicios o favores, sino que, por el contrario, se le observa en Unidad con él. Si bien algunas personas imaginan que deberían ver a Dios como si estuviera frente a ellos, Eckhart no concuerda con tal idea. Su crítica a las formas tradicionales de entender a Dios puede resumirse en lo siguiente: "quieren ver a Dios con los mismos ojos con que ven a una vaca y quieren amar a Dios como aman a una vaca, a la que quieren por su leche, su queso y los beneficios que obtienen (...) pero estos no aman rectamente, más bien aman su interés personal" (Eckhart, 2011f: 93-94).

El abandono (gelâzenheit) del mundo y las cosas, que propone el Maestro, lleva al reencuentro con el origen, en donde las cosas eran en sí mismas 
una unidad. Es evidente que el abandono, como salida y entrada recíprocas, tiene un aspecto doble y vinculante, el cual es tan propio de la paradoja mística. Eckhart refiere en su sermón Cómo tenéis que vivir, el ejemplo de los que él llama los vasos espirituales. Estos últimos, en distinción a los vasos materiales, son idénticos a aquello que contienen, pues lo contenido debió tomar la forma del contenedor para poder ser vertido en él. Por el contrario, en los vasos materiales comunes, el contendor es diferente al contenido y por ello le puede contener. En lo que aplica a la mística eckhartiana, Dios no puede recibir nada que no sea de su misma naturaleza y el hombre, como vaso espiritual, debe hacerse uno con Dios para que él pueda darse. El modo de asemejarse a Dios es ser como él en el espacio antecedente a la creación, como una Nada de la cual todo surge. En esto se entiende que la divinidad del hombre es semejante a la de Dios en razón de la naturaleza increada que habita aún en él. Por ello, el florecer, surgir y fluir, adecuaciones eckhartianas de emanantismo neoplatonismo, sólo es posible cuando el hombre se niega a sí mismo y logra asemejarse a la nada de la que surgió cuando aún la creación no era tal.

Todo lo anterior apunta a que la imagen de la deidad está impresa en el alma, en aquello más espiritual que tenga el hombre. En ese sentido, "no hay devenir en Dios, sino sólo un ahora, un devenir sin devenir, un ser de nuevo, sin renovación, y ese devenir es su ser" (Eckhart, 2011h: 103). Dado que el movimiento en la nada originaria no implicaba el tiempo, se entiende por derivación que "nada es tan contrario a Dios como el tiempo" (Eckhart, 2011h: 102). Para Eckhart, todo esto no puede ser expresado correctamente con el lenguaje; la comprensión de tales conjeturas sólo tiene puede suceder en el interior, y aunque exista la voluntad de expresar las vivencias y experiencias que conlleva no puede eludirse la reducción de la virtud en la explicación debido al roce que el hombre ha tenido con el resto de las criaturas. Es decir, pertenecer a la creación provocó en el hombre su inclusión en la esfera del tiempo, a partir de lo cual su imperfección imperó por sobre la imagen de la deidad que en él operó, y que él constituía, antes de su origen. Al estar impregnado en una experiencia terrenal que deviene en atributos personales debido a los aprendizajes, el individuo, buscando entenderse distinto y fabricando sus propios procedimientos de diferenciación, se ha alejado de la conexión íntima con su esencia de vacuidad. Viviendo, el individuo no puede más que rondar, acercarse tímidamente a la explicación veraz de su antecedente material. En tales condiciones, "el hombre debería aceptar voluntariamente la muerte y morir, con el fin de que se le conceda un ser mejor" (Eckhart 2011e: 86). En la creación, siendo parte de ella, Dios está oculto para el hombre, quien ha creado imágenes de él que le terminan por distorsionar 
pues su imagen es la no imagen. De tal manera, el proceso de desvelamiento de Dios consiste en desnudarle de toda imagen y ahí, en el espacio vacío derivado del desprendimiento de sus ropajes, emergerá la imagen desnuda de Dios, su ser no-siendo lo que hemos creído.

La comprensión de que "Dios está más allá de nombres y es inefable" (Eckhart, 2011j: 116), es un preámbulo necesario para la desnudez del hombre ante su Dios desnudo. De tal modo, "si el hombre se une a Dios por amor es desnudado de las imágenes y formado y transformado en la uniformidad divina, en la que él es uno con Dios" (Eckhart, 2011g: 99). Para que esto sea logrado, es ineludible que el individuo aprenda y viva auténticamente pobre de espíritu.

\section{EL VACÍO Y LA POBREZA DE ESPÍRITU}

El sermón Pobres de espiritu es uno de los más importantes de Eckhart. En sus páginas, el dominico explica lo que debe suceder para obtener la pobreza que permite acceder parcialmente a la sabiduría divina. Un hombre pobre, dice el Maestro, "es el que nada quiere, nada sabe y nada tiene" (Eckhart, 2011i: 106). La pobreza eckhartiana auténtica no sólo se refiere a un alejamiento de las cosas y atributos del mundo, sino también, y por encima de todo, al distanciamiento de las imágenes, nombres, concepciones, consideraciones, explicaciones y comprensiones de lo que Dios es. No querer nada, o, mejor dicho: querer nada, implica, incluso, no querer a Dios, lo que se haya entendido de él. Al no querer comprender se logra un extrañamiento de las cosas del mundo y de Dios mismo, es decir, aquello que el hombre sepa de Dios y que, por ende, le tuvo que haber sido enseñado por otro que, a la vez, lo aprendió en su momento. El maquillaje de Dios a través de las palabras le distorsiona, la suposición de su voluntad le desvanece, el culto a lo que se considera que él es le destroza en añicos, se vuelve nimiedad. Contrario a ello, desde la hermenéutica eckhartiana, se asume que sólo podrá existir comprensión en la medida en que el hombre se transforme, como vaso espiritual, en el objeto de comprensión. El sujeto se objetiva así en lo que ahora le posee. El Dios desnudo, la deidad no parlante previa a la creación, recibe con sus imaginarios brazos a quien, desnudado ante él, se entrega sin medida en la más absoluta pobreza. Asimismo, "mientras el hombre tenga la voluntad de cumplir la preciosa voluntad de Dios, no posee la pobreza de la que hablamos; pues en él todavía hay una voluntad que quiere satisfacer a Dios y eso no es la pobreza correcta" (Eckhart, 2011i: 107).

La pobreza eckhartiana está asociada coherentemente al vacío, pues mientras más lleno está el hombre de las representaciones de Dios, en el entendido que sólo representaciones de él pueden hacerse en vida, menos 
lleno está de la deidad. La invitación final de Eckhart, cerrando el sermón mencionado es didáctica y clara: "Rogamos a Dios que nos vacíe de Dios y que alcancemos la verdad y la disfrutemos eternamente, allí donde los ángeles supremos y las moscas y las almas son iguales, allí, donde yo estaba y quise lo que fui y fui lo que yo quise" (Eckhart, 2011i: 108). Es comprensible, entonces, que Eckhart atribuye al hombre una existencia fusionada al origen primigenio, desde la cual pudo elegirse, en concordancia con la esencia de la que todo ha emanado, la vida y las condiciones que en ella debían experimentarse. Su idea de una pre-existencia se reitera en la afirmación siguiente: "Si el hombre quiere ser pobre en voluntad, debe poder querer y desear tan poco como quiso y deseó cuando no era" (Eckhart, 2011i: 108). Podrá argumentarse que este no ser del que habla Eckhart implica que el hombre no podría querer algo, sin embargo, desde la óptica del ejemplar dominico que nos ocupa, el hombre era, entonces, uno con la deidad, no sólo parte de él, es decir, "cuando el hombre estaba en el ser eterno de Dios, no vivía en él nada más; es más, lo que allí vivía era él mismo" (Eckhart, 2011i: 108).

De tal modo, quedan en entredicho todas las afamadas propuestas de cumplir con la voluntad de Dios, pues "un hombre pobre es aquel que no quiere cumplir la voluntad de Dios y que vive de tal forma que está vacío de su propia voluntad y de la de Dios, tal como lo era cuando todavía no era. De esta pobreza decimos que es la pobreza sublime" (Eckhart, 2011i: 110). En el ser surgido del principio, en el que Dios está por encima del ser y de toda diferencia, dice Eckhart: "allí era yo mismo, allí me quise a mí mismo y me conocí a mí mismo en la voluntad de crear a este hombre que soy yo" (Eckhart, 2011i: 111). En ese tenor, lo que hoy sucede está establecido con anterioridad, o, al menos, fue aprobado que pudiese acontecer. Nada puede turbar al individuo pues todo sigue un plan maestro.

Aquel que nada quiere, nada sabe y nada posee (nibt enwil und nibt enweir. und nibt enhât), tiene por meta lograr vivir como un no nacido (ungeborn), condición irrenunciable para retrotraerse a la deidad, punto desde el cual no se puede morir jamás. Para lograr tal estado, el hombre no sólo reconoce que ha fluido de Dios, sino que atraviesa la creación misma, su condición mundana incluida, para ser (y no sólo contemplar) lo que realmente es. Esto supone una transfiguración tal que ya no importa la identidad pues se es la no identidad:

En el atravesar, sin embargo, en donde permanezco libre de mi propia voluntad y de la voluntad de Dios y de todas sus obras y de Dios mismo, entonces estoy por encima de todas las criaturas y no soy ni Dios ni criatura, soy más bien lo que fui y lo que seguiré siendo ahora y siempre. Entonces siento un impulso que me debe lanzar por encima de todos los ángeles. En 
dicho impulso siento una riqueza tan grande que Dios no me puede bastar con todo lo que Dios es, en cuanto Dios, con todas sus obras divinas; pues en ese atravesar me doy cuenta de que yo y Dios somos uno (Eckhart, 2011i: 111).

Este "atravesar" al que refiere Eckhart consiste en el camino, viaje, proceso de transfiguración, odisea o trayecto que el hombre debe recorrer para lograr llegar a la deidad, en la cual, hecho una nada y vacío por completo, se vuelve uno con ella. El cruce o atravesar es, en cierto modo, una superación de toda representación posible y, dado que el hombre no puede evitar representar, es necesario que deje de ser lo que es para lograr un estado de no-representación. Es obligatorio distinguir entre Dios y Deidad desde los parámetros eckhartianos. Primeramente, si ubicamos un momento atemporal, lejano a la creación, en forma antecedente (o circular, considerando la negativa de observar el tiempo como una línea), en el que todo lo que hoy existe no fuese tal como se muestra actualmente, no tendría sentido hablar de Dios. Tampoco puede afirmarse que "no era", pues podría referirse, en todo caso, a una deidad en la que Dios era lo que era antes de Dios (er was, daz er was), en función de que estaba fuera de la creación, no era creador y se mantenía anterior a todo, incluso de sí mismo.

Ahora bien, cuando acontece la creación, o el surgir del ser, es difícil intuir una deidad, es decir, un Dios en sí mismo del que no haya emanado algo, ni criaturas, cosas, personas, naturaleza o cosmos. Lo que queda es lo que se concibe como una Sustancia que ha fluido en lo que se derivó de ella. En ese orden de ideas, la intención última de todo lo creado, incluidas las criaturas, no podría ser Dios, entendido como aquello que ya está contenido en el contenedor que recibió la emanación, pues no es posible ser finalidad de sí mismo ni ir hacia el sitio en el que ya se está, ni querer ser lo que ya se es. Se deriva de tal situación, que el fin último de lo creado es el retorno a la deidad antecedente de la divinidad presente en lo emanado, es decir, aquello que está (sin estar) más allá del ser y de las criaturas. El "atravesar" referido por Eckhart es el reconocimiento de la deidad previa a la derivación cósmica de Dios, es decir, lo que he dado el nombre de Nadeidad. Considerado así, a lo que aspira el hombre es a un vaciarse de Dios (gotes ledic werden).

Eckhart realiza la siguiente distinción en el mismo orden de ideas:

La Deidad y Dios son realidades tan distintas como el Cielo y la Tierra (...) "Dios" sólo aparece cuando todas las criaturas lo enuncian (...) Todas las creaturas hablan pues de Dios. ¿Y por qué no hablan de la Deidad? Todo lo que está en la Deidad es Unidad y no se puede decir nada de ello. Dios opera, 
pero la Deidad no opera; ella no tiene por lo demás ninguna obra que efectuar; no hay operación en ella; y nunca ha puesto los ojos en ninguna operación. Dios y la Deidad difieren como la operación y la No operación (Eckhart, 1980: 189).

Asimismo, el Maestro criticó a los teólogos que dicen que Dios es un ser y un ser inteligible que conoce todas las cosas; él, por el contrario, afirma que: "Dios ni es un ser ni es inteligible, ni conoce esto ni lo otro. Por eso Dios está vacío de todas las cosas y por ello es todas las cosas" (Eckhart, 1980: 189).

\section{EL ANILLO DEL SER Y SU CENTRO VACÍO}

La imagen de un anillo coadyuva eficientemente a la analogía que realiza Eckhart sobre Dios. Si bien el anillo tiene una circunferencia, lo central en él es el espacio vacío que permite que la circunferencia material lo sea. En Dios, según Eckhart, existe un anillo configurado por el ser, pero su centro es vacío esencialmente. Este entendimiento de la divinidad como un círculo sin centro, le permite estar, a la vez, en todas partes, pues todo lo que es le rodea y configura. El centro de Dios, así, no tiene un lugar o sitio específico, no está en un espacio natural; en esa óptica, es inaccesible para quien no se transfigure en tal naturaleza. Dios, al estar en sí mismo, es decir, en su vacío rodeado de ser, está fuera del tiempo y, por ello, no se contamina de lo que el tiempo toca. El factor de la temporalidad, como atributo decadente de la existencia, está fuera de Dios.

Para el hombre, la manera particular de estar fuera del tiempo, la única posible, es la muerte. Si "lo que toca el tiempo es mortal" (Eckhart, 2011e: 87), sólo muriendo se saldría de la condición de mortalidad; la paradoja está presente en ello mismo, la muerte nos salva de la mortalidad, al permitir que la mortalidad se logre consumar. En este fundamento se sustenta Eckhart cuando afirma que "debemos comportarnos como si estuviéramos muertos, de modo que ni el amor ni el sufrimiento nos conmuevan" (Eckhart, 2011e: 83); sólo en tales condiciones se podrá compartir parcialmente el centro vacío de la divinidad, a pesar de que aún rodee al hombre una periferia del ser. No obstante, la muerte que propone Eckhart (2011e: 86) es dadora de vida, pues "para Dios nada muere; todas las cosas viven en él". La muerte dadora de vida no debe ser cualquier muerte, sino que es menester que sea profunda (grunttôt), pues sólo así será posible que permita al hombre (aquello que aún de él quede) a penetrar el abismo sin fondo de la divinidad (abgrunt).

En el camino a la pureza de la vacuidad plena, "no se debe amar a Dios a causa de su reino de los cielos o de cualquier otro deseo, más bien 
hay que amarlo a causa de la bondad que es en sí mismo. Pues quien ama a causa de cualquier otra cosa, éste no vive en él, sino en aquello a causa de lo cual lo ama" (Eckhart, 2011g: 97). Lo primero que el hombre debe tomar en cuenta si quiere vivir en Dios, según Eckhart, es negarse a sí mismo y a todas las cosas, asimismo "que no dependa de nada que los sentidos toquen interiormente" (Eckhart, 2011g: 96). En la radical mística negativa que propone el Maestro, el hombre "no debe aceptar a Dios, por su bondad o justicia, sino que debe comprenderlo en la substancia pura y limpia en la que él se comprende a sí mismo en su pureza" (Eckhart, 2011g: 97). En el camino del atravesar las cosas del mundo, el hombre ha de apartarse de las simbolizaciones de Dios y contemplar que "Dios es un Verbo, un Verbo no dicho" (Eckhart, 2011j: 114), por lo que cualquier cosa que se diga de él (eso) implicará una distorsión. Es por ello que el dominico enfatiza imperativamente: "Aparta de Dios todo cuanto lo reviste y tómalo puro en el vestidor donde está descubierto y desnudo en sí mismo. Entonces permaneceréis en él” (Eckhart, 2011g: 97). Es altamente significativo que este "tomar puro" a Dios adviene una permanencia fusionada en él, al ser ambas entidades una sola en la vacuidad plena. De tal manera, los pretenciosos rituales que enfatizan las formas y convencionalidades están privados de la comprensión que la mística radical eckhartiana, centrada en una dialéctica negativa, propone. Concretamente, "aquellos que se apegan a la penitencia y al ejercicio exterior (...) se les llama santos en razón de las apariencias, pero en el interior son asnos, pues no saben discernir la verdad divina" (Eckhart 2011i: 106).

Quien auténticamente permanece en Dios, desde la visión de la mística nihilista eckhartiana, comprende que:

a) "Entre él y Dios no hay diferencia, sino que son uno" (Eckhart, 2011g: 97), ahí donde el vacío unifica y hace ser, no siendo, una sola Unidad.

b) Asimismo, el hombre "toma su bienaventuranza de la pureza en donde Dios mismo la toma" (Eckhart, 2011g: 97), por lo que la fuente es, más que compartida, unificada. De la Nadeidad originaria, tanto Dios como el hombre han bebido para sustanciarse y ahora, por fin, unidos tras la transfiguración del hombre, son portados por un mismo vaso espiritual que integra, fusiona y confluye.

c) Además, el hombre que padecido la muerte a partir de su atravesar por el mundo "tiene un saber con el saber de Dios y tiene una acción con la acción de Dios y un conocer con el conocer de Dios" (Eckhart, 2011g: 98), ya no hay Señor y seguidor, amo y esclavo, Padre e hijo, Dios y creyente, dado y receptor, altura y nimiedad, perfecto e imperfecto, sino que las divisiones se han perdido, las distancias anonadado y la relación extirpado a partir de una igualdad. 
d) En tales condiciones, "Dios nace siempre en el hombre" (Eckhart, 2011g: 97) cuando el hombre se ha vuelto vacuo tal como la deidad primera.

e) Del mismo modo en que en el hombre nace Dios, "aquel hombre nace siempre en Dios" (Eckhart, 2011g: 98).

Resumiendo, la deidad original brotada de la nada, la Nadeidad, dejó de ser lo que era en el momento en que se rodeó del anillo del ser en todo lo creado, es decir, en aquello que, aunque emanó de ella ya no era ella. La creación da sentido a la invocación de Dios, un Dios que, eventualmente, es distorsionado por la misma creación pensante a partir de imágenes maquiladas en la creatividad fantasiosa de quienes se sienten iluminados para dotar al mundo de las representaciones de Dios. Ahí, en el tumulto masificador de los que creen conocer a Dios poniéndole un nombre, Eckhart propone un desvelamiento de la deidad, su comprensión más allá de las configuraciones sobre Dios. Sólo así, en el desvestir a Dios de los ropajes impuestos, se logrará desgajar lo que cubre a la deidad hasta que, eliminadas todas las vestiduras, nombres y postulados, permanezca el espacio vacío al que el hombre se adhiere cuando es capaz de extrañarse incluso de sí mismo y de lo que ha creído que era. Esta negación de todo, en su afirmación de la nada restante, aquello que queda cuando ya no queda algo, unifica al espíritu del hombre que, purificado, está listo para rodearse del ser y penetrar el anillo puro y virginal de Dios: la Nadeidad. Aplazando el encuentro definitivo con ella, en la muerte profunda y definitiva, al hombre sólo le resta separarse de lo que sabe, aislarse de lo creado aun sabiéndose parte de ello, pero enalteciendo en grado sumo su pertenencia al origen puro del que brotó en un principio junto a Dios. El hombre, como fruto de la nada, ha de volverse un ser separado del cual surja, sublime y elocuente, la razón de su existir.

Como puede observarse, la hermenéutica eckhartiana, columpiada en la tensión entre lo que puede ser comprendido y aquello que está más allá de toda comprensión, implica el saberse en posibilidad de atravesar los límites del conocimiento; a la vez, eso que se ha comprendido como noción, a pesar de la voluntad por ser expresado, se estrella y desvanece en el muro de la inefabilidad, se rehúsa a contentarse con una simbolización distorsionante y permite que la respuesta permanezca contenida en el silencio. El círculo hermenéutico propuesto por Eckhart implica que alejarse de cualquier signo de Dios es la entrada a su reino puro y vacuo. En la dimensión en la que salir es entrar, bajar es subir y alejarse es acercarse, asumirse sin Dios es poseerlo, negarlo es afirmarlo, el ateísmo es un óptimo teísmo en el que la ofensa se transfigura en una sofisticada adoración; en la misma medida logra entenderse que no hay separación posible del ser (entitario) emanado de Dios que nos albergará hasta que la Nadeidad 
sea el reino no reinante prometido, aquel en el que la unión será irrenunciable. La comprensión de este tipo no tiene lugar hasta que se abandona el mundo, el tiempo y el devenir implicado, sólo así logra ser comprendida por completo en el punto en el que la comprensión no es posible al ya no ser. Este sitio en el que se suspende todo acontecer, está por encima de toda concepción posible y es a lo que el Maestro refiere del modo siguiente: "Hay una luz sobre las luces en donde el alma escapa a todas las luces 'en las montañas de lo alto' en donde ya no hay más luz" (Eckhart, 20111, p. 131). Coincido con Castañeda cuando afirma que: "Decir 'Dios es nada' apunta a lo fundamental de una experiencia de la Divinidad, su innombrabilidad, su in-tangibilidad, lo oculto de su misterio y de su presencia" (Castañeda, 2011: 114).

Basta con intuir, contemplar someramente, que la luz más resplandeciente es la que al no dejarnos ver nos compenetra con las tinieblas; así se coincide con Eckhart (2011n: 142) cuando afirma que "libres de trabas están quienes ordenan todas sus actividades según el modelo de la luz eterna; y ésos están junto a las cosas, pero no en las cosas. Están muy cerca de ellas y por eso mismo no tienen menos que si estuviesen allí arriba en el círculo de la eternidad"; precisamente, el "círculo de la eternidad" (umberinge der êwicheit) al que refiere el Maestro es equivalente al "anillo del ser", siempre y cuando se advierta que es posible y real una Deidad sin ser (gotheit âne wesen), la Nadeidad.

\section{PREÑADOS DE LA NADA EN EL SIN MODO}

La búsqueda de Dios, para el Maestro Eckhart, implica una no búsqueda, pues cuando algo se busca se le ha dado un modo, el cual se desea verificar en el encuentro. La categorización de Dios en modos específicos es una afrenta a lo que es, de ahí se deriva que no pueda ser encontrado mientras se indague a través de los modos prestablecidos. Es por ello que "a Dios hay que tomarlo en tanto que modo sin modo y en tanto que ser sin ser, pues no tiene ningún modo" (Eckhart, 2011k: 126). Si Dios no tiene modo, se sigue por consecuencia que es innombrable y que "está más allá de toda palabra en la pureza de su fondo, en donde Dios no puede contener ninguna palabra ni discurso, en donde es inefable e indecible para todas las criaturas" (Eckhart, 2011m: 134). De tal manera no se puede establecer una guía para el encuentro con la divinidad pues "no hay camino hacia Dios" (Eckhart, 2011k: 119); asimismo, no hay escalas de mayor o menor acercamiento a la divinidad y "quien todavía anda en el subir y en el crecer en la gracia y en la luz, éste aún no ha llegado a Dios" (Eckhart, 2011k: 119). Según el dominico, debe tenerse cuidado respecto a las maneras de tomar a Dios, enfáticamente advierte que, si es tomado "como 
una luz o como un ser o como un bien, y reconoces alguna cosa de él, eso no es Dios" (Eckhart, 2011k: 122). En ese camino de negación, la única alternativa es despojar las ideas preconcebidas, en un despojo que es analogía de la nada, pues "estar lleno de todas las criaturas es estar vacío de Dios" (Eckhart, 2011p: 171), a la vez, si se permite un vaciado personal, si el esfuerzo llega hasta el punto de la separación de las ideas y de las representaciones entonces se penetra al estado en el que "estar vacío de todas las criaturas es estar lleno de Dios” (Eckhart, 2011p: 171).

Permanecer en el sin modo es facultar la posibilidad de estar preñados de la nada, y de tal condición surge el fruto de la nada misma que Eckhart equipara con Dios. En el sermón titulado El fruto de la nada, el cual se caracteriza por contener claramente los elementos apofáticos de la mística del dominico, se expone la narración siguiente:

A un hombre le pareció una vez en un sueño - era un sueño de vigilia- que estaba preñado de la nada, como una mujer lo está de un niño, y en esa nada había nacido Dios; él era el fruto de la nada. Dios había nacido en la nada. Por eso él dice: "se levantó del suelo y, con los ojos abiertos, nada veía". Veía a Dios, en quien todas las criaturas son nada. Veía a todas las criaturas como una nada, pues él (Dios) tiene en sí el ser de todas las criaturas (Eckhart, 2011k: 123).

Este pasaje refiere la esencia de la mística nihilista eckhartiana al reconocer que Dios fructifica en el hombre en la misma medida en que éste ha logrado ser preñado de la nada; tal consecuencia sólo es lograble a través de un ejercicio de vacío paulatino, constante y esmerado. Dejar ir las concepciones de lo divino podría ser uno de los aspectos más complejos para aquellos que han sido habituados a reconocer a Dios en modalidades, suponiendo que es una entidad visible o que puede captarse cuando se saber ver, siendo que, por el contrario, cegarse es un requisito. La propuesta eckhartiana implica una actitud de cautela, concretamente recomienda: "A quien diga que Dios está aquí o allí, no le creáis (...). Dios es una luz verdadera; quien quiera verla debe ser ciego y debe mantener a Dios fuera de todas las cosas" (Eckhart, 2011k: 123). La ceguera que hace ver a Dios al no ver, queda representada en el pasaje bíblico (Hch, 9, 8) en el que se advierte que "Saulo se levantó del suelo y, con los ojos abiertos, nada veía". Según Eckhart (Eckhart, 2011k: 123): “él nada veía, y eso era Dios. Dios es una nada y Dios es alguna cosa. Lo que es alguna cosa, también eso es nada"; por ello, "quien con nada habla de Dios lo hace correctamente" (Eckhart, 2011k: 123). San Agustín solía decir que cuando Saulo no veía nada veía a Dios. Es posible invertir una palabra, de tal modo que es más claro así: cuando veía la nada, veía a Dios. Dios habita en el vacío. La 
visión extática del que llegó a ser San Pablo supuso una suspensión de facultades en la que logró estar en contacto con la nada de la deidad a partir de una hermenéutica espiritual extratemporal y transhistórica. Dios y el hombre heredan su deidad del fondo abismal que es la nada.

Tal como afirma Eckhart en su Tratado del hombre noble, no es necesario realizar añadiduras a Dios, sino, por el contrario, despojarle de las imágenes que le representan. De tal modo, su mística no implica menos un sumar y más un restar, se vuelve evidente la necesidad de despojar lo sobrante, que es todo lo tangible. El ejemplo del Maestro al respecto es muy claro: "Cuando un maestro hace una imagen de madera o piedra, no introduce la imagen en la madera, sino que corta las astillas que han ocultado y recubierto la imagen; no añade nada a la madera, sino que golpea y esculpe la cobertura y saca la escoria y entonces resplandece lo que estaba oculto debajo" (Eckhart, 2011o: 158).

No es sumar lo que procede al ejercicio de la mística, sino, por el contrario, una resta, un disminuir, un hacer menos, un abrir hacia la desnudez. Cuando el hombre realiza consigo ese mismo escrutinio es capaz de concebir que está preñado de una nada cuyo emerger es retrasado, por lo que permanece sobrante y de más en el ser del hombre; los pensamientos, anhelos, deseos, emociones y consideraciones a las formas obstaculizan el parto de la nada, por ello su fruto, que es Dios en la mística eckhartiana, no florece con libertad.

Concebir el fruto derivado de estar preñado de la nada es un logro poco accesible para el hombre contemporáneo que, distraído por las modalidades de los convencionalismos religiosos permanece sin acceso a la mística nihilista al estar lleno de formas y estatutos. Concretamente, los seis grados de experiencia mística asociados a lo propuesto por el Maestro Eckhart, de acuerdo a Vega, son los siguientes:

El primer grado del hombre interior consiste en el culto a la imagen, cuando el templo se hace aun necesario; con el segundo grado da comienzo la vida ascética señalada por la autonegación, el rechazo a lo humano y la preparación de una base matricial absolutamente virgen; pero incluso a esa nada fundamental debe morir el espíritu del hombre noble, que en este punto se halla más allá de cualquier consideración moral en su camino de separación y pérdida de toda referencia; el cuarto grado es la muerte a toda voluntad y la entrega amorosa a Dios; el quinto es la adquisición de la sapientia dei; y el sexto la perfección del camino de conversión iniciado en el primer grado: el desnudamiento de la propia imagen y la transfiguración (entbildet und überbildet) (Vega, 2011: 273). 
El planteamiento ascético que logra coronarse con el punto más alto de la mística eckhartiana está contenido en el tratado Del ser separado (Eckhart, 2011p) en el que el despojo es llevado a la radicalidad nihilista que, aún sin buscar fructificar premeditadamente, logra una consecuencia salvífica.

\section{LA SEPARACIÓN COMO MODO DE VIDA}

Ser separado (abegescheidenheit) es un término que expresa el fundamento de la mística eckhartiana y sus seguidores. Esencial en el pensamiento teológico, sugiere un vaciado místico de todo lo cognoscible, incluido el yo, con la intención de retornar a la unión mística con la divinidad en función de su coincidir en la Nadeidad. De tal modo, "el puro ser separado todo lo supera, pues todas las virtudes tienen alguna mirada en las criaturas, mientras que el ser separado está vacío de todas las criaturas" (Eckhart, 2011p: 166); ser separado "es la más alta y mejor virtud por la cual el hombre puede unirse mejor y más rápido con Dios" (Eckhart, 2011p: 166), logrando con ello asemejarse a la imagen que él era en Dios en el estado en el que "no había diferencia alguna entre él y Dios antes de que Dios creara a las criaturas" (Eckhart, 2011p: 166). Eckhart reitera la condición primigenia del hombre en la que no había diferencia, antes de la creación, entre Dios y él. El nihilismo de la mística de Eckhart no supone una destrucción por sí misma, sino que es un destruir que invita a la reivindicación en lo Absoluto.

Cuando la separación se vuelve un modo de vida se encuentran añadiduras significativas. Quien está en el punto en que se asemeja a la nada obtiene todo como ganancia, pues se establece en el estado en que todo es una suma tras la resta continua. Para Eckhart, el ser separado es una virtud mayor que el amor mismo, pues incluso "que Dios sea Dios le viene de su ser separado inmóvil, y del ser separado le viene su pureza, su simplicidad y su inmutabilidad" (Eckhart, 2011p: 171). De tal modo, en este caso contrario a la postura paulina, Eckhart entiende el amor como una virtud secundaria en comparación al ser separado, pues quien ama percibe a Dios como un bien y como un alguien específico, lo cual implica un obstáculo para la unión con Dios si se considera que "nadie puede ir tan lejos como para nombrar a Dios" (2011k: 122), por lo que Dios es el mayor ser separado.

La pura nulificación, o la pura nada (blôzen nibte) que el hombre realiza es facultativa debido a que la capacidad originaria de la nada se ve fortalecida cuando el individuo es capaz de vaciarse voluntariamente de los falsos ídolos, de sus propios sostenes racionales, de sus facultades intelectualistas desentrañadas, para depositarse en la contemplación de lo incontemplable. 
En esto se coincide con Eckhart (2011p: 176) cuando reconoce que "para que el corazón tenga predisposición a lo más elevado deba permanecer sobre una pura nada y en ello consiste también la mayor posibilidad que pueda haber".

El corazón auténticamente separado no pide absolutamente nada y su oración no es otra cosa que ser uniforme con Dios, al tiempo que se vuelve "libre del amor a causa del amor y oscuro a causa de la luz" (Eckhart, 2011p: 178). Con su ser separado, el individuo logra abandonar el mundo confuso de las formas y llega al estado de la no forma, el cual es constituido por Dios mismo en su carácter de deidad. En el extrañamiento (entfremdung) que procede del ser separado, el yo logra una muerte que libera al ser íntimo, aunque continúe la existencia física. Si se considera a Dios como fundamento de todo lo existente, se observará que él mismo está sustentado en nada, de tal modo que, según Eckhart, encuentra en el hombre que ha logrado ser separado un alma desfondada que se vuelve su hábitat debido a su proximidad con la nada, de tal modo que se anula la creaturalidad del hombre y se logra una conexión con la deidad contenida en Dios. En ese sentido, "el ser separado, en la medida en que es nada, puede aspirar a llenarse del ser de Dios" (Vega, 2011: 277). Es por esto que en su poema El grano de mostaza, Eckhart (2011q: 186) se expresa de la siguiente forma: " $\mathrm{O}$, alma mía, sal fuera, Dios entra! Hunde todo mi ser en la nada de Dios".

\section{CONCLUSIÓN}

La mística que Eckhart propuso y vivió fue motivo de persecución incluso en su misma orden debido a que algunos de sus hermanos veían con disgusto su forma de predicar al pueblo. Esto constituyó, en cierto modo, una vivencia en carne propia de lo que Eckhart refirió como separación. Forzado por Juan XXII, el dominico Nikolaus von Strassburg realizó una investigación sobre los escritos alemanes del Maestro Eckhart; las indagaciones se centraron inicialmente en el Liber Benedictus y se procedió a declarar peligrosas las proposiciones contenidas en tal escrito. Es comprensible que una enseñanza que eludía los modos para centrarse en el sin modo de Dios, resultaría estorbosa para los predicadores de las formas.

Como el lector seguramente podría predecir, la historia del proceso contra Eckhart estuvo saturada de inconsistencias. El 27 de marzo de 1329, el Papa Juan XXII publicó la Bula In agro dominico (Acta 65), en la que se consigna que Eckhart quiso saber más de lo que era necesario y oscurecía la verdadera fe en muchos corazones. Se advirtió además que Eckhart había sido "seducido, en efecto, por aquel padre de la mentira, 
que frecuentemente adopta la figura de un ángel de luz para difundir la oscuridad tenebrosa y odiosa de los sentidos" (Juan XXII, 2011: 233). De tal modo, el Maestro fue juzgado por su libre lectura de la vida y la mística, así como su intención precisa de liberar a sus oyentes de las formas con las que la autoridad modela a Dios, incluido su nombre y voluntad. Eckhart murió a inicios de 1328 a la espera de una resolución a las acusaciones, nunca leyó la Bula referida.

Ser tratado como herético por aprobar los escritos de Eckhart no detuvo a Johannes Tauler y Henrich Seuse, quienes, enseguida, se volvieron en continuadores de la escuela de Eckhart. Por su parte, contemporáneamente, se considera a Alois Hass $(2009$; 2012) como uno de los mayores estudiosos de la obra del Maestro. Cabe decir que, en 1992, en un proceso derivado de varias peticiones de los miembros de la Orden de Predicadores, se levantó la condena católica a los escritos del Maestro Eckhart por la vía de la Congregación para la Doctrina de la Fe, dirigida entonces por Joseph Ratzinger.

Cabe clarificar enfáticamente que la congruencia en el decir y el actuar del Maestro revisten un interés profundo para la consecución de un nihilismo de alcances místicos. Asumir la nada de la deidad, la Nadeidad, restando las contrariedades políticas y colectivas que de ello se pueda derivar, está en consonancia con la invitación directa de Eckhart (2011m: 137): "separa todo añadido de la deidad y tómala desnuda en sí misma".

La herencia eckhartiana crecerá oportunamente en la medida en que su mensaje, cuyo atravesar didáctico le ha llevado al hombre común un proceso de casi setecientos años de comprensión, sea tomado, asimilado y asumido por aquellos que han logrado hacer de su propio fondo un modo sin modo en el que puede nacer, nuevamente, el fruto de la nada.

\section{REFERENCIAS}

-Castañeda, J. (2011). Dios y ser. Una aproximación desde Eckhart y Heidegger. Teologia y Sociedad (9), 107-127.

-Eckhart, M. (1980). Obras escogidas. Barcelona: Visión libros.

-Eckhart, M. (2011a). El templo vacío. En M. Eckhart, El fruto de la nada y otros escritos (pp. 53-60). Madrid: Alianza.

-Eckhart, M. (2011b). La virginidad del alma. En M. Eckhart, El fruto de la nada y otros escritos (pp. 61-68). Madrid: Alianza.

-Eckhart, M. (2011c). Vivir sin porqué. En M. Eckhart, El fruto de la nada y otros escritos (pp. 69-74). Madrid: Alianza.

-Eckhart, M. (2011d). Dios y yo somos uno. En M. Eckhart, El fruto de la nada y otros escritos (pp. 75-82). Madrid: Alianza

-Eckhart, M., (2011e). El anillo del ser. En M. Eckhart, El fruto de la nada y otros escritos (pp. 83-88). Madrid: Alianza. 
-Eckhart, M. (2011f). Cómo tenéis que vivir. En M. Eckhart, El fruto de la nada y otros escritos (pp. 89-95). Madrid: Alianza.

-Eckhart, M. (2011g). La imagen desnuda de Dios. En M. Eckhart, El fruto de la nada y otros escritos (pp. 96-100). Madrid: Alianza.

-Eckhart, M. (2011h). La imagen de la Deidad impresa en el alma. En M. Eckhart, El fruto de la nada y otros escritos (pp. 101-104). Madrid: Alianza.

-Eckhart, M., (2011i). Los pobres de espíritu. En M. Eckhart., El fruto de la nada y otros escritos (pp. 105-113). Madrid: Alianza.

-Eckhart, M. (2011j). Dios es un verbo que se habla a sí mismo. En M. Eckhart, El fruto de la nada y otros escritos (pp. 114-117). Madrid: Alianza.

-Eckhart, M. (2011k). El fruto de la nada. En M. Eckhart., El fruto de la nada y otros escritos (pp. 118-126) Madrid: Alianza.

-Eckhart, M. (20111). La montaña verde. En M. Eckhart, El fruto de la nada y otros escritos (pp. 127-132). Madrid: Alianza.

-Eckhart, M., (2011 m). El enviado. En M. Eckhart, El fruto de la nada y otros escritos (pp. 133-137). Madrid: Alianza.

-Eckhart, M. (2011n). Marta y María. En M. Eckhart, El fruto de la nada y otros escritos (pp. 138-149). Madrid: Alianza.

-Eckhart, M. (2011o). Tratado del hombre noble. En M. Eckhart, El fruto de la nada y otros escritos (pp. 153-165). Madrid: Alianza.

-Eckhart, M. (2011p). Del ser separado. En M. Eckhart, El fruto de la nada y otros escritos (pp. 166-180). Madrid: Alianza.

-Eckhart, M. (2011q). El grano de mostaza. En M. Eckhart, El fruto de la nada y otros escritos (pp. 183-186). Madrid: Alianza.

-Filippi, S. (2003). Martín Heidegger y la Mística Eckhartiana. Invenio, 6(11), 3339.

-Haas, A. (2009). Viento de lo absoluto. ¿Existe una sabiduría mistica de la posmodernidad? Madrid: Siruela.

-Haas, A. (2002). Maestro Eckhart: figura normativa para la vida espiritual. Barcelona: Herder.

-Juan XXII (2011). Bula In agro dominico. En M. Eckhart, El fruto de la nada y otros escritos (pp. 232-238). Madrid: Alianza.

-Nishitani, K. (2003). La religión y la nada. Madrid: Siruela.

-Tanabe, H. (2014). Filosofía como Metanoética. Barcelona: Herder.

-Vega, A. (2011). "Notas". En M. Eckhart, El fruto de la nada y otros escritos (pp. 31 32). Madrid: Alianza.

Sumario: Introducción; 1. Nihilismo moral como pauta de la mística; 2. El fondo de Dios; 3. Unidad con Dios en la nada; 4. El vacío y la pobreza de espíritu; 5. El anillo del ser y su centro vacío; 6. Preñados de la nada en el sin modo; 7. La separación como modo de vida; Conclusión; Referencias. 